\title{
Effect of memantine on calcium signaling in hippocampal neurons cultured with $\beta$-amyloid
}

\author{
V.M. Shkryl, V.V. Ganzha, E.A. Lukyanetz \\ O.O. Bogomoletz Institute of Physiology, National Academy of Sciences of Ukraine, Kyiv; \\ e-mail: elena@biph.kiev.ua
}

\begin{abstract}
Alzheimer's disease (AD) is the most common type of dementia and is characterized by accumulating amyloid $(A \beta)$ plaques and neurofibrillary tangles in the brain. Excessive stimulation of glutamate receptors, mainly NMDA-type, causes intense entry of calcium ions into cells and is a key early step in glutamateinduced excitotoxicity, resulting in many neurological diseases, including AD. Memantine, an NMDA receptor antagonist, blocks NMDA receptors and reduce the influx of calcium ions into neuron. In our experiments, we have modeled AD on cultured rat hippocampal neurons to test the effects of memantine on calcium signaling in neurons. Our results show that the neuroprotective effect of memantine could be provided not only through the inhibition of NMDA receptor current but also through the suppression of voltage-dependent $\mathrm{Ca}^{2+}$ channels, most likely L-type. This study suggests that NMDA receptor antagonist memantine can protect hippocampal neurons from calcium overloading induced by AB1-42 amyloid exposure via blocking $\mathrm{Ca}^{2+}$ channels.

Keywords hippocampal neuron culture; A $\beta$-amyloid; NMDA; memantine; calcium; calcium homeostasis; Alzheimer's disease.
\end{abstract}

\section{INTRODUCTION}

Alzheimer's disease (AD) is clinically characterized by progressing cognitive impairment, memory loss, and behavioral changes. Currently, more than 26.6 million people worldwide suffer from this disease, and this number is growing sharply every year. By 2050, the number of patients is expected to quadruple to more than 106 million globally, and an estimated 1 from 85 people will be subject to the disease [1] For this reason, both scientific and clinical studies covering all aspects of AD have become extremely relevant and have expanded greatly in recent decades. So far, the etiology of $\mathrm{AD}$ remains unknown. However, it was shown many factors had been involved in AD, and several hypotheses were proposed to explain the onset and progression of the neurodegenerative process observed in this disorder. One such hypothesis is "the amyloid hypothesis", which supports the idea that accumulation of neurotoxic forms of beta-amyloid peptide $(A \beta)$ leads to (C) V.M. Shkryl, V.V. Ganzha, E.A. Lukyanetz amyloid plaques, which play a special role in the pathogenesis of AD $[2,3]$. Finally, A $\beta$ plaques cause neuronal loss. Recent evidences suggest that soluble $A \beta$ oligomers, rather than plaques, are a major cause of synaptic dysfunction leading to neurodegeneration. The soluble $A \beta$ oligomer has been shown can interact with glutamatergic N-methyl-D-aspartate (NMDA) receptors and other proteins involved in maintaining glutamate homeostasis as uptake and release.

Calcium plays a particularly important role in neuronal cells, where it mediates numerous vital physiological processes and plays a central role in controlling synaptic plasticity [4]. For normal functioning, neurons require extremely precise control of $\mathrm{Ca}^{2+}$ concentration in certain compartments. One of the common factors underlying AD pathogenesis is a violation of the regulation of $\mathrm{Ca}^{2+}$ in neurons. Constant disturbances in $\mathrm{Ca}^{2+}$ signaling have significant consequences for neurons' health and functionality throughout the organism's life 
and form the basis of "the calcium hypothesis" in $\mathrm{AD}$ [5]. At rest, cytosolic $\mathrm{Ca}^{2+}$ is maintained at a low nanomolar concentration by pumps, buffers, and transport mechanisms. $\mathrm{Ca}^{2+}$ entry from the extracellular environment is carried out by activation of voltage-gated $\mathrm{Ca}^{2+}$ channels (VGCC), ionotropic glutamate channels (NMDA), and acetylcholine receptors [6]. Besides, intracellular depots - mitochondria and endoplasmic reticulum (ER) - regulate calcium in the cell [7-9].

It is known that memantine, a selective antagonist of NMDA-receptors, is used in medical practice for treatment of different types of dementia, including AD $[10,11]$. We previously tested meantime action on memory tests in rats [12-15]. These experiments have shown that memantine markedly increases the fulfillment of a conditioned reflex in old and young rats, which indicated its effect on memory processes. Therefore, this study aimed to test memantine's effects on calcium signaling in cultured hippocampal neurons treated with $A \beta 1$ 42 (AD modeling).

\section{METHODS}

All experimental procedures were performed following the European Commission Directive (86/609/EEC) and were approved by the local Animal Ethics Committee of the Bogomoletz Institute of Physiology (Kyiv, Ukraine). All efforts were made to minimize the number and suffering of animals used. Studies were performed on rat hippocampal culture neurons using a common technique described earlier [16, 17]. In our studies, we used a control set of cells, which were incubated in standard conditions - nutrient medium, which included $90 \%$ of the Minimum Essential Media (MEM, Sigma-Aldrich, USA), $2.2 \mathrm{~g} / 1 \mathrm{NaHCO}_{3}, 10 \%$ horse serum (Gibco, USA), $10 \mu \mathrm{g} / \mathrm{ml}$ insulin and antibiotics: $50 \mathrm{IU} /$ $\mathrm{ml}$ benzylpenicillin sodium and $50 \mu \mathrm{g} / \mathrm{ml}$ streptomycin sulfate. Prolonged culturing of CNS cells in vitro is widely used for AD modeling $[18,19]$. In our study, the model was obtained by 24-hour incubation of hippocampal culture neurons with A $\beta 1-42$ (Sigma-Aldrich, USA) at a final concentration of $2 \mu \mathrm{M}$.

We used the electric field stimulation (EFS) of neurons to depolarize cell membrane and fill endoplasmic reticulum with $\mathrm{Ca}^{2+}$. Field stimulated $\mathrm{Ca}^{2+}$ transients were induced with a standard protocol by lowering two parallel platinum electrodes $(20 \div 25 \mathrm{~mm}$ apart $)$ into the chamber in near contact with the surface and then passing 15 current pulses at $15 \mathrm{~Hz}$ of 1 msec between the electrodes, yielding fields of $\sim 12 \div 15 \mathrm{~V} / \mathrm{cm}$ across the surface of the coverslip [20]. The resistance between medium and cells is negligible as electrodes are not in direct contact with cells, and EFS is delivered to cells through the medium.

To measure intracellular calcium concentration, we used fluorescent microscopy and calcium-sensitive dye Fura-2 AM as was described previously $[21,22]$. Before the experiment, neurons were stained in a solution of Fura-2 AM dye $(5 \mu \mathrm{M})$ for $30 \mathrm{~min}$. Coverslips with neurons were then washed and placed in the chamber with the experimental solution included in $\mathrm{mM}: \mathrm{NaCl}-140.0 ; \mathrm{KCl}-2.0 ; \mathrm{CaCl}_{2}-2.0$; $\mathrm{MgCl}_{2}-2.0$; HEPES $-10.0 ; \mathrm{pH}=7.4$. To induce $\mathrm{Ca}^{2+}$ transient we used depolarization solution, its composition was equivalent to bath solution described above except that $50 \mathrm{mM}$ of $\mathrm{NaCl}$ was replaced by $\mathrm{KCl}$. Using a digital video camera, we recorded changes in the level of fluorescence intensity of Fura-2 dye in the soma of neurons at 340 and $380 \mathrm{~nm}$ excitation. Cell $\mathrm{M}$ software (Olympus, Japan) was used for data collection, and data analysis was performed using the IDL programming environment (ITT Visual Information Solutions). We performed further data analysis, and the ratio of 340 to $380 \mathrm{~nm}$ fluorescence intensity (ratio; F340/F380) was calculated. We estimated the data according to the protocol described in [23] to calculate F340/ F380 by subtracting the resulting background level (calculated outside the cells). Dynamic changes in this indicator assessed changes in the level of free calcium in neurons' cytosol. 
The obtained results were processed using variation statistics using Origin software (Microcall Inc., USA). Numerical data are given as mean \pm mean error. The data were tested to be normally distributed. Intergroup comparison was performed using analysis of variance (ANOVA). If intergroup differences were found, the Tukey test was used. The results were considered statistically significant at $P<0.05$.

\section{RESULTS}

In the first series of experiments, we used hippocampal culture neurons in control conditions. We used the protocol of experiments to apply 3 EFS stimuli ( $1 \mathrm{~s}$ duration of each) with $3 \mathrm{~s}$ intervals between them, Fig. 1A. These were necessary to fill intracellular depots. After that, we applied caffeine $(10 \mathrm{mM})$ for $5 \mathrm{~s}$ to induce $\mathrm{Ca}^{2+}$ release from the ER stores by ryanodine receptors (RyRs) and estimate their contribution to the $\mathrm{Ca}^{2+}$ signaling of these cells. Accordingly, after the next three-time EFS, we applied a high $\mathrm{KCl}$ solution $(50 \mathrm{mM})$ to depolarize the membrane and induce $\mathrm{Ca}^{2+}$ transients evoked by the activity of voltage-operated $\mathrm{Ca}^{2+}$ channels, Fig. 1A.

Further, we conducted the same set of the protocol but in the presence of $20 \mu \mathrm{M}$ memantine to test its effect on the mentioned participants of the $\mathrm{Ca}^{2+}$ signaling in the same tested neurons. As it can be seen, the application of memantine in extracellular solution led to a decrease in calcium loading in endoplasmic depot and decreased the amplitude of calcium transient during depolarization of the membrane by $\mathrm{KCl}$ but slightly influenced the basal free calcium.

In the next series of experiments, we used the same protocol but tested neurons, which were incubated $24 \mathrm{~h}$ before the experiments with
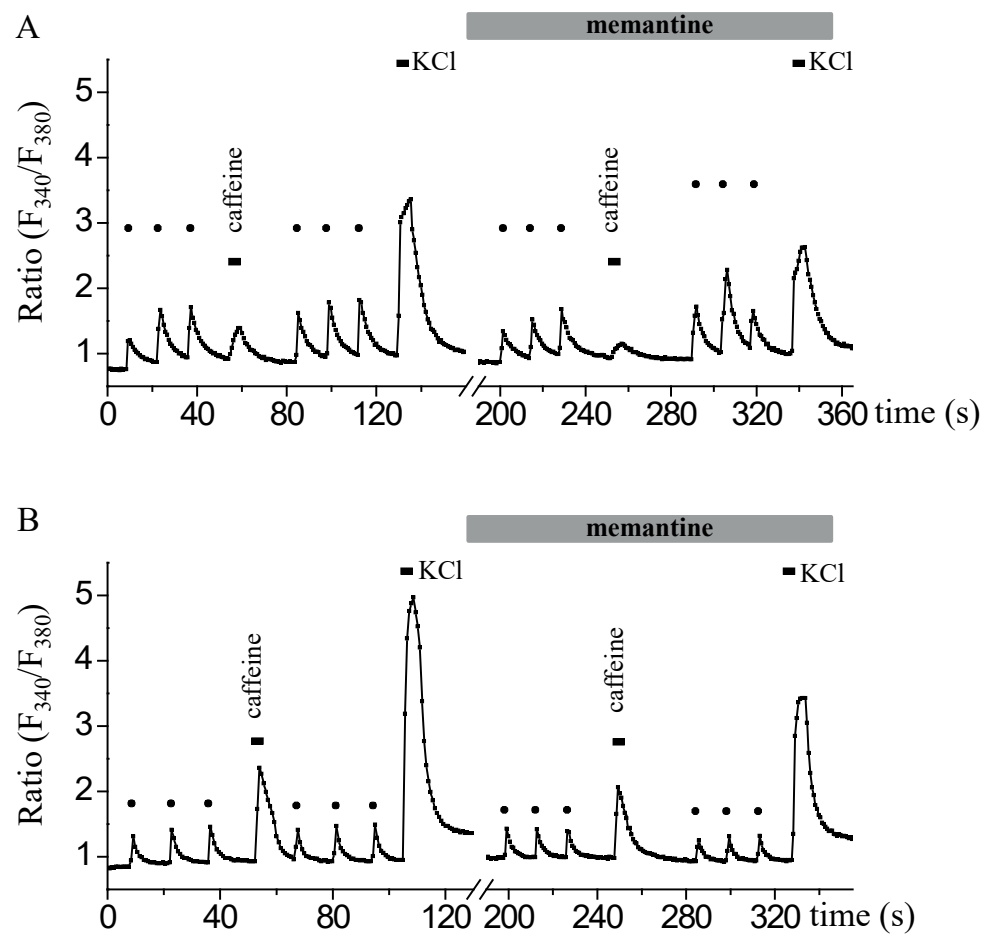

Fig. 1. The action of memantine on changes in the intracellular calcium levels under control conditions and after incubation A $\beta 1-42$. A - representative registration of changes in intracellular concentration in value of ratio of free calcium on the cultured neuron in control and the presence of $20 \mu \mathrm{M}$ memantine. Peaks were induced by three-time EFS (black circles), application of $10 \mathrm{mM}$ caffeine $(5 \mathrm{~s})$, and 5-second depolarization with $50 \mathrm{mM} \mathrm{KCl}$; B - the same stimuli were used for the neuron which was previously incubated during $24 \mathrm{~h}$ with $2 \mu \mathrm{M} \mathrm{A} \beta 1-42$ 
$5 \mu \mathrm{M} A \beta 1-42$. An example of such registrations is presented in Fig. 1B. We first measured calcium signal changes before memantine was added to the external solution and then measured from the same cell in the presence of $20 \mu \mathrm{M}$ of this reagent. Such a form of experiment reduced the differences between the registrations' conditions and allowed a convincing study of memantine's effect. As can be seen from the presented registrations of calcium signal changes, $20 \mu \mathrm{M}$ memantine induced a significant decrease in values of $\mathrm{Ca}^{2+}$ transients evoked by $5 \mathrm{~s}$ depolarization $(50 \mathrm{mM} \mathrm{KCl})$ and $5 \mathrm{~s} 10 \mathrm{mM}$ caffeine application compared to the control.

Statistics data of observed effects are presented in Fig. 2. Thus, the ratio value of basal level of free calcium under control conditions was $1.05 \pm 0.07(\mathrm{n}=15)$ and $0.95 \pm 0.02$ $(\mathrm{n}=14)$ in the presence of $20 \mu \mathrm{M}$ memantine. These values in the neurons which were previously incubated for $24 \mathrm{~h}$ with $2 \mu \mathrm{M} \mathrm{A} \beta 1-42$ in culturing medium, were $0.97 \pm 0.04(\mathrm{n}=20)$ and $1.01 \pm 0.03(\mathrm{n}=16)$ in the presence of 20 $\mu \mathrm{M}$ memantine.

The level of free calcium (in ratio value) before the second $\mathrm{Ca}^{2+}$ transient caused by EFS under control conditions was $1.07 \pm 0.04$ $(n=15)$ and $1.02 \pm 0.02(n=14)$ in the presence of $20 \mu \mathrm{M}$ memantine. These values in the cells, which were previously incubated for $24 \mathrm{~h}$ in culture medium with $2 \mu \mathrm{M} \mathrm{A} \beta 1-42(\mathrm{~A} \beta)$, were $1.17 \pm 0.07(\mathrm{n}=20)$ and $1.07 \pm 0.04(\mathrm{n}=16)$ in
A
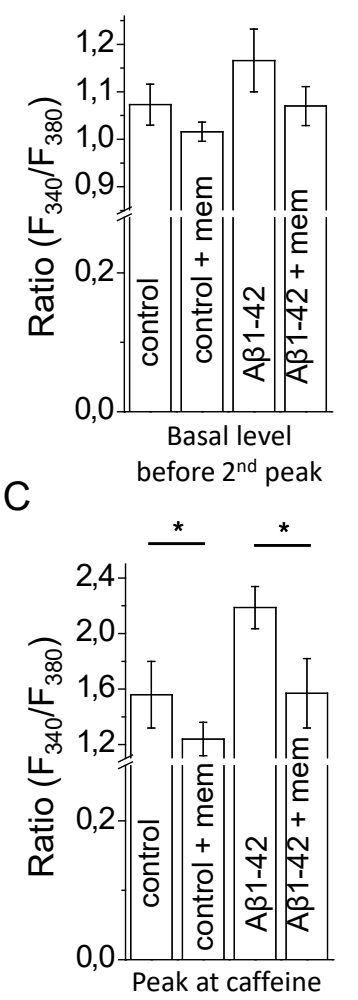

B
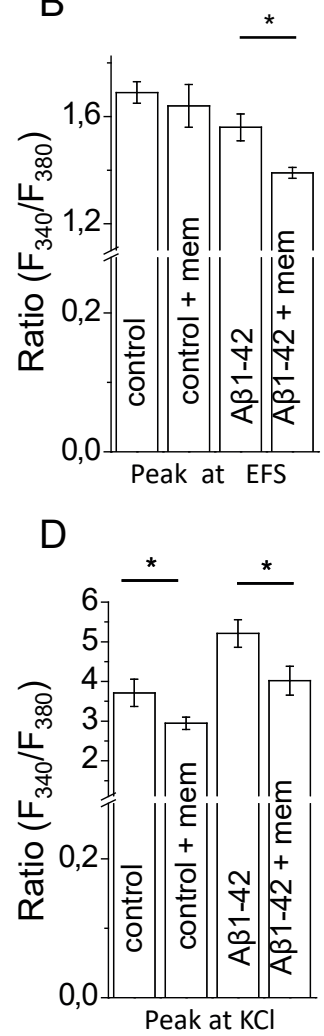

Fig. 2. Diagrams represent statistical data of memantine's effect on the changes in the level of intracellular calcium concentration in value of ratio. Part $\mathrm{A}$ is mean values of the basal $\mathrm{Ca}^{2+}$ level before induction of the second $\mathrm{Ca}^{2+}$ transient caused by EFS; part $\mathrm{B}$ is the mean values of the peak of the second $\mathrm{Ca}^{2+}$ transient caused by EFS; part $\mathrm{C}$ is the mean values of the peak of signal evoked by $5 \mathrm{~s}$ application of $10 \mathrm{mM}$ caffeine; part $\mathrm{D}$ is the mean values of the peak of the $\mathrm{Ca}^{2+}$ transient evoked by the application of the depolarizing solution $(50 \mathrm{mM} \mathrm{KCl} ; 5 \mathrm{~s})$. For all cases, data represent values in control conditions (control), during application of $20 \mu \mathrm{M}$ memantine (mem) and for case $24 \mathrm{~h}$ preincubation of neurons with $2 \mu \mathrm{M} A \beta 1-42(\mathrm{~A} \beta)$. $* \mathrm{P}<0.05$ 
the presence of $20 \mu \mathrm{M}$ memantine, as shown in the diagram $2 \mathrm{~A}$.

Memantine almost unchanged the peak value of $\mathrm{Ca}^{2+}$ transients caused by EFS. Thus, the mean peak value of $\mathrm{Ca}^{2+}$ transients was reduced from $1.69 \pm 0.04(\mathrm{n}=15)$ in control to $1.64 \pm 0.08$ $(\mathrm{n}=14)$ after memantine application. Under $\beta$-amyloid treatment, this parameter was significantly reduced from $1.56 \pm 0.05(n=19)$ in control conditions to $1.39 \pm 0.02$ in the presence of memantine $(\mathrm{n}=16, \mathrm{P}<0.05)$. The data are presented in Fig. 2B.

Statistical data concerning RyRs endoplasmic depo involvement in $\mathrm{Ca}^{2+}$ responses are presented in Fig. 2C. We used caffeine, an agonist of RyRs, to induce $\mathrm{Ca}^{2+}$ release from the endoplasmic reticulum, which can appear as $\mathrm{Ca}^{2+}$ transient during registrations. As shown in Fig. 2C, the peak values of calcium signals induced by $10 \mathrm{mM}$ caffeine application were significantly reduced in the presence of $20 \mu \mathrm{M}$ memantine in comparison with control values. They decreased from $1.56 \pm 0.24(\mathrm{n}=14)$ in control to $1.24 \pm 0.12(\mathrm{n}=12, \mathrm{P}<0.05)$ after memantine action. In the neurons, which were previously treated with $\beta$-amyloid, this value was reduced from $2.16 \pm 0.36(\mathrm{n}=17)$ in control to $1.57 \pm 0.25(\mathrm{n}=16, \mathrm{P}<0.01)$ after memantine application.

We also calculated statistical data concerning the peaks of $\mathrm{Ca}^{2+}$ transients induced by $5 \mathrm{~s}$ depolarizing solution $(50 \mathrm{mM} \mathrm{KCl})$ applications. They also were significantly reduced from $3.71 \pm$ $0.34(\mathrm{n}=15)$ in control to $2.95 \pm 0.16(\mathrm{n}=14$, $\mathrm{P}<0.05)$ after $20 \mu \mathrm{M}$ memantine applications. In the neurons previously incubated with $A \beta 1$ 42 , this parameter was also noticeably decreased by memantine, Fig. 2D. These values were reduced from $5.21 \pm 0.35(\mathrm{n}=19)$ in control to $4.02 \pm 0.36(\mathrm{n}=16, \mathrm{P}<0.05)$ after memantine application.

\section{DISCUSSION}

Glutamate is the major fast excitatory neurotransmitter and is involved in almost all
CNS functions, especially in the cortex and hippocampus: $70 \%$ of all excitatory synapses in the CNS use glutamate as a neurotransmitter. Ionotropic glutamate receptors, responsible for rapid neural communication at excitatory synapses, contain three subfamilies: $\alpha$-amino 3-hydroxy 5-methyl 4-isoxazole-propionic acid (AMPA), kainate receptors, and NMDA receptors. Among them, NMDA receptor ion channels are the most permeable to $\mathrm{Ca}^{2+}$, which can, in turn, function as a second messenger in different signaling pathways [24].

The hippocampus has a high density of glutamate NMDA receptors and is extremely important for learning and memory. Normally, they are activated only in certain physiological processes, such as the induction of synaptic plasticity, and are capable of long-term potentiation of synaptic transmission, which is considered one of the key mechanisms for providing higher functions: learning, memory, behavioral and other reactions.

NMDA receptor has been implicated as a mediator of neuronal damage associated with many neurological disorders, including ischemia, epilepsy, brain injury, dementia, and neurodegenerative disorders such as AD. Pathological elevations in glutamate levels and other disturbances that alter the resting membrane potential (e.g., metabolic disturbances) may cause over-stimulation of NMDA receptors, which induces excitotoxicity and promotes cell death. This process underlies the potential mechanism of neurodegeneration that occurs in AD.

Under normal synaptic transmission, NMDAR channels are blocked by $\mathrm{Mg}^{2+}$ inside the channel and are activated only for a short period. However, under pathological conditions, the normal $\mathrm{Mg}^{2+}$ block of the ion channels is removed and abnormally enhances the activity of NMDA receptors. Excessive receptor activation leads to an excessive influx of $\mathrm{Ca}^{2+}$ into the neuron, which then triggers various processes that can lead to necrosis or apoptosis [25]. Various pathologies, such as $\mathrm{A} \beta$ oligomer action, 
oxidative stress, mitochondrial dysfunction, elevated glutamate concentrations, and neuronal inflammation, have been associated with hypersensitivity and activity glutamatergic system, leading to neuronal dysfunction and cell death in AD [26].

Memantine, a non-competitive NMDA receptor antagonist, blocks the NMDA ion channels with fast kinetics. Complete depolarization of the membrane leads to memantine removing from the channel, which provides normal synaptic transmission. It is suggested that these properties underlie memantine's ability to ensure the receptor's normal physiological functioning while disrupting receptor pathological activation. It has also been shown that NMDA receptor blockade alleviates $\mathrm{A} \beta$-induced degeneration in rat hippocampal neurons [24]. Preclinical data suggest that NMDA receptor-mediated excitotoxicity may be associated with the effects of abnormal $\mathrm{A} \beta$ deposition during $\mathrm{AD}$.

In our experiments, we tested the effects of memantine on the components of calcium intracellular signaling, such as basal $\mathrm{Ca}^{2+}$ level in the cytoplasm, changes in $\mathrm{Ca}^{2+}$ transients evoked by membrane depolarization with EFS, activation of voltage-depended $\mathrm{Ca}^{2+}$ channels by high $\mathrm{KCl}$ solution and $\mathrm{Ca}^{2+}$ release from ryanodine receptors of the endoplasmic reticulum. As well, we estimated these parameters in neurons, which were treated with $A \beta 1-42$ (cell model of AD). It is proved that $A \beta 1-42$ increased all tested parameters in our experiments except for EFS' amplitude, which had a tendency to be decreased, Fig. 2 . Thus, the ratio $\left(\mathrm{F}_{340} / \mathrm{F}_{380}\right)$ of basal level of $\mathrm{Ca}^{2+}$ increased by $8.7 \%$, the peak of $\mathrm{KCl}$-transient $40.32 \%$, caffeine peak - 40,2\%, whereas the EFS peak was slightly decreased by $7,7 \%$. These data show that $A \beta 1-42$ significantly affects membrane voltage-dependent channels, increasing the flow of calcium into the cell and, consequently, more filling of the ER-depot and the release of calcium from it into the cytoplasm during RyRs agonist action.

Our experiments have shown that memantine decreased all tested indicators in control condi- tions and neurons treated with the $A \beta 1-42$ (AD model) but with different degrees. It only tended to decrease the basal level, and this value was in the range not exceeding $8 \%$. Also, the effect was weakly expressed in the case of EFS, it did not exceed $3 \%$ in control and was more noticeable in cells treated with A $\beta 1-42(\sim 11 \%)$. The most pronounced effect of memantine was found in the case of caffeine and $\mathrm{KCl}$ applications. It was $20.5 \%$ in the case of ER-depots and $20.7 \%$ in the case of $\mathrm{Ca}^{2+}$-channels. In the cells treated with $\mathrm{A} \beta 1-42$, these values were some more -28.2 and $22.8 \%$ correspondingly, Fig. $2 \mathrm{C}$, D.

Interestingly, the effects of $\mathrm{A} \beta 1-42$ and memantine on calcium peaks at EFS were significantly less pronounced than those at the depolarization of membrane by $\mathrm{KCl}$. It was previously shown that EFS could affect calcium channels, $\mathrm{Ca}^{2+}$-stores, stretch channels, $\mathrm{Na}^{+}$channels [27]. It was also known that EFS is better to use mainly for modulation of electrosecretory coupling at the nerve endings where it can be better investigated by evoking synaptic release with electrical pulses. We suppose that EFS evoked electrical pulses are very short in duration to produce remarkable membrane depolarization. Our experiments show that EFS is not well suited for studying the chemical compound effects, but it can be successfully used mainly to fill ER depots with $\mathrm{Ca}^{2+}$.

Although it is known that memantine is an antagonist of NMDA receptors, our research has shown that it can partially block L-type calcium channels of hippocampal neurons in the concentration of $20 \mu \mathrm{M}$. This observation is in line with data obtained on a single retinal ganglion cell of adult frogs Rana temporaria [28]. In these experiments, the authors have shown that memantine $(30 \div 45 \mu \mathrm{M})$ largely inhibited the L-type $\mathrm{Ca}^{2+}$ channels. Their results suggested that memantine's neuroprotective effect could be provided not only through the inhibition of NMDA receptor currents but also through suppressing L-type channels. Our results obtained on rat hippocampal neurons completely support 
above-mentioned conclusion that memantine also suppresses voltage-dependent $\mathrm{Ca}^{2+}$-channels, which are most likely of L-type.

Acknowledgments. This work was supported from funds of National Academy of Sciences of Ukraine to support the development of priority areas of research $S R N$ (state registration number) 0118U007344, 0120U001281 and $0116 U 004470$.

The authors of this study confirm that the research and publication of the results were not associated with any conflicts regarding commercial or financial relations, relations with organizations and/or individuals who may have been related to the study, and interrelations of co-authors of the article.

\section{В.М. Шкриль, В.В. Ганжа, О.О. Лук’янець ВПЛИВ МЕМАНТИНУ НА КАЛЬЦІСВУ СИГНАЛІЗАЦІЮ У ГІПОКАМПАЛЬНИХ НЕ- ВРОНІВ КУЛЬТИВОВАНИХ 3 $\beta$-АМІЛОЇДОМ}

Інститут фізіологї ім. О.О. Богомольия НАН Украӥни, Kuïв;e-mail: elena@biph.kiev.ua

Хвороба Альцгеймера (XА) є найпоширенішим видом деменції і характеризується накопиченням $\beta$-амілоїдних $(\mathrm{A} \beta)$ бляшок та нейрофібрилярних клубків у мозку. Надмірна стимуляція глутаматних рецепторів, переважно NMDA-типу, спричиняе інтенсивне надходження іонів кальцію в клітини і $€$ ключовим раннім етапом індукованої глутаматом ексайтотоксичності, що призводить до багатьох неврологічних захворювань, включаючи ХА. Антагоніст NMDA-рецепторів, мемантин, блокує NMDAрецептори і зменшує вхід іонів кальцію в нейрон. У наших експериментах ми використовували моделювання $\mathrm{XA} \mathrm{на} \mathrm{культурі} \mathrm{нейронів} \mathrm{гіпокампа} \mathrm{щурів} \mathrm{для} \mathrm{тестування}$ ефекту мемантину на сигналізацію кальцію в нейронах. Наші результати, отримані на нейронах гіпокампа щурів, показують, що нейропротекторний ефект мемантину може бути забезпечений не тільки інгібуванням NMDAрецепторів, але також за допомогою пригнічення потенціалзалежних $\mathrm{Ca}^{2+}$-каналів, найбільш ймовірно L-типу. Антагоніст NMDA-рецепторів мемантин може захищати нейрони культури гіпокампа від перевантаження кальцієм, спричиненого впливом A $\beta 1-42$ блокуванням $\mathrm{Ca}^{2+}$-каналів.

Ключові слова: культура нейронів гіпокампа; $\beta$-амілоїд; NMDA; мемантин; кальцій; гомеостаз кальцію; хвороба Альцгеймера.
В.М. Шкрыль, В.В. Ганжа, Е.А. Лукьянец

ВЛИЯНИЕ МЕМАНТИНА НА КАЛЬЦИЕВУЮ СИГНАЛИЗАЦИЮ В ГИППОКАМПАЛЬНЫХ НЕЙРОНОВ КУЛЬТИВИРУЕМЫХ С ß-АМИЛОИДОМ

Болезнь Альцгеймера (БА) является наиболее распространенным видом деменции и характеризуется накоплением $\beta$-амилоидных (A $\beta$ ) бляшек и нейрофибриллярных клубков в мозгу. Чрезмерная стимуляция глутаматных рецепторов, преимущественно NMDA-типа, вызывает интенсивное поступление ионов кальция в клетки и является ключевым ранним этапом индуцированной глутаматом эксайтотоксичности, что приводит ко многим неврологическим заболеваниям, включая БА. Антагонист NMDA-рецепторов мемантин блокирует их и уменьшает вход ионов кальция в нейроны. В наших экспериментах мы использовали моделирование БА на культуре нейронов гиппокампа крыс для тестирования эффекта мемантина на сигнализацию кальция в нейронах. Наши результаты, полученные на нейронах гиппокампа крыс, показывают, что нейропротекторный эффект мемантина может быть обеспечен не только за счет ингибирования NMDA-

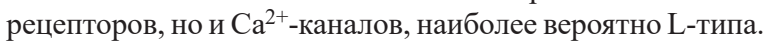
Антагонист NMDA-рецепторов мемантин может защищать нейроны культуры гиппокампа от перегрузки кальцием, вызванной влиянием A $\beta 1-42$ путем блокирования $\mathrm{Ca}^{2+}$-каналов.

Ключевые слова: культура нейронов гиппокампа; $\beta$-амилоид; NMDA; мемантин; кальций; гомеостаз кальция; болезнь Альцгеймера.

\section{REFERENCES}

1. Prasansuklab A, Tencomnao T. Amyloidosis in Alzheimer's disease: The toxicity of amyloid beta $(A \beta)$, mechanisms of its accumulation and implications of medicinal plants for therapy. Evid Based Complement Alternat Med. 2013;2013:413808.

2. Tyshchenko YN, Lukyanetz EA. The role of betaamyloid in norm and at Alzheimer's disease. Fiziol Zh. 2020;66(6):88-96.

3. Kravenska Y, Nieznanska H, Nieznanski K, Lukyanetz E, Szewczyk A, Koprowski P. The monomers, oligomers, and fibrils of amyloid- $\beta$ inhibit the activity of mitoBKCa channels by a membrane-mediated mechanism. Biochimica et Biophysica Acta (BBA) - Biomembranes. 2020;1862(9):183337.

4. Pchitskaya E, Popugaeva E, Bezprozvanny I. Calcium signaling and molecular mechanisms underlying neurodegenerative diseases. Cell Calcium. 2018;70:87-94.

5. Khachaturian ZS. Hypothesis on the regulation of cytosol calcium concentration and the aging brain. Neurobiol Aging. 1987;8(4):345-6.

6. Demuro A, Parker I, Stutzmann GE. Calcium signaling and amyloid toxicity in Alzheimer disease. J Biol Chem. 
2010;285(17):12463-8.

7. Kostyk PG, Kostyuk E, Lukyanetz EA. Calcium ions in brain function - from physiology to pathology. Kyiv: Naukova Dumka; 2005. 152 p.

8. Kostyk PG, Kostyuk EP, Lukyanetz EA. Intracellular calcium signaling - structures and functions. Kyiv: Naukova Dumka; 2010. 176 p.

9. Kostyuk PG, Lukyanetz EA. Intracellular calcium signaling - basic mechanisms and possible alterations. In: Ayrapetyan SN, Markov MS, editors. Bioelectromagnetics Current Concepts. NATO Security Through Science Series. Netherlands: Springer 2006. p. 87-122.

10. McShane R, Westby MJ, Roberts E, Minakaran N, Schneider L, Farrimond LE, et al. Memantine for dementia. Cochrane Database System Reviews. 2019; 3(3):Cd003154.

11. Peng D, Yuan X, Zhu R. Memantine hydrochloride in the treatment of dementia subtypes. J Clin Neurosci. 2013;20(11):1482-5.

12. Gorbachenko VA, Lukyanetz EA. Effects of memantine on the passive avoidance test in young rats. Fiziol $\mathrm{Zh}(\mathrm{Kiev}$, Ukraine : 1994). 2020;66(5):3-10.

13. Tyshchenko Y, Lukyanetz EA. Effects of memantine on behavioral indices of rats in the open field. Neurophysiology. 2017;49(6):453-7.

14. Gorbachenko VA, Kruchenko JO, Chereda IS, Lukyanetz EA. Measurements of the time parameters of conditioned food reflex in rats under memantin treatment with using of automatic registration system. Bull Taras Shevchenko Nat Univ Kyiv Ser: Radiophysics and Electronics. 2015;1(23):23-6.

15. Kruchenko ZA, Gorbachenko VA, Chereda IS, Lukyanetz EA. Effect of memantine on motor behavioral phenomena in rats of different ages. Neurophysiology. 2014;46(5):448-51.

16. Kravenska EV, Chopovska VV, Yavorskaya EN, Lukyanetz EA. The role of mitochondria in the development of Alzheimer's disease. Tavrichesky MedBiol Bull. 2012;15(3/2):147-9.

17. Kravenska EV, Ganzha VV, Yavorskaya EN, Lukyanetz EA. Effect of cyclosporin a on the viability of hippocampal cells cultured under conditions of modeling of
Alzheimer's disease. Neurophysiology. 2016;48(4):246-51.

18. Beesley S, Olcese J, Saunders C, Bienkiewicz EA. Combinatorial treatment effects in a cell culture model of Alzheimer's disease. J Alzheimers Dis. 2017;55(3):1155-66.

19. Dubey SK, Ram MS, Krishna KV, Saha RN, Singhvi G, Agrawal M, et al. Recent expansions on cellular models to uncover the scientific barriers towards drug development for Alzheimer's disease. Cell Mo Neurobiol. 2019;39(2):181-209.

20. Shkryl VM, Maxwell JT, Domeier TL, Blatter LA. Refractoriness of sarcoplasmic reticulum $\mathrm{Ca}^{2+}$ release determines $\mathrm{Ca}^{2+}$ alternans in atrial myocytes. Am J PhysiolHeart Circulat Physiol. 2012;302(11):H2310-H20.

21. Shkryl VM, Kostyuk PG, Lukyanetz EA. Dual action of cytosolic calcium on calcium channel activity during hypoxia in hippocampal neurones. NeuroReport. 2001;12(18):4035-9.

22. Shkryl VM, Nikolaenko LM, Kostyuk PG, Lukyanetz EA. High-threshold calcium channel activity in rat hippocampal neurones during hypoxia. Brain Res. 1999;833(2):319-28.

23. Shkryl VM. Error correction due to background subtraction in ratiometric calcium measurements with $\mathrm{CCD}$ camera. Heliyon. 2020;6(6):e04180.

24. Olivares D, Deshpande VK, Shi Y, Lahiri DK, Greig NH, Rogers JT, et al. N-methyl D-aspartate (NMDA) receptor antagonists and memantine treatment for Alzheimer's disease, vascular dementia and Parkinson's disease. Current Alzheimer Res. 2012;9(6):746-58.

25. Zipfel GJ, Babcock DJ, Lee JM, Choi DW. Neuronal apoptosis after CNS injury: the roles of glutamate and calcium. J Neurotrauma. 2000;17(10):857-69.

26. Danysz W, Parsons CG. Alzheimer's disease, $\beta$-amyloid, glutamate, NMDA receptors and memantine - searching for the connections. Brit J Pharmacol. 2012;167(2): 324-52.

27. Mycielska ME, Djamgoz MB. Cellular mechanisms of direct-current electric field effects: galvanotaxis and metastatic disease. J Cell Sci. 2004;117(Pt 9):1631-9.

28. Baginskas A, Kuras A, Grigaliūnas A. Inhibition of dendritic L-type calcium current by memantine in frog tectum. Medicina (Kaunas, Lithuania). 2013;49(9):409-14.

Received 02.02.2021 